\title{
AUTES TECH \\ (AUTOMATIC ELECTRIC SCARECROW TECHNOLOGY)
}

\author{
M Taufik Nur Hidayat ${ }^{1}$, Desi Rahmawati ${ }^{2}$, Ulvah Windi Rahayu ${ }^{3}$, Kuat Indartono ${ }^{4}$ \\ 1,2,3,4Program Studi Teknik Informatika \\ STMIK Amikom Purwokerto \\ Email: muhammadtaufik841@gmail.com ${ }^{1}$,dhesi_rahmawati99@yahoo.co.id ${ }^{2}$, \\ ulvahwindirahayu51@gmail.com ${ }^{3}$, indartono@amikompurwokerto.ac.id ${ }^{4}$
}

\begin{abstract}
ABSTRAK
Teknologi dibidang pertanian yang semakin berkembang dengan bantuan teknologi yang semakin canggih sangat membantu para petani dalam meningkatkan hasil pertanian yang mereka kelola sehingga tidak menyebabkan kerugian setiap masa penen. Autes Tech yang merupakan sebuah alat yang membantu masyarakat khususnya para petani menjelang musim panen ketika hama burung mulai meyerang ketika musim panen dengan sistem electronic alat ini menggunakan bantuan aki atau accumulator dalam penggunaan daya dan menggunakan sistem peregerakan dengan bantuan timer setiap pergerakan 5 menit sekali. Alat ini dapat digunakan oleh para petani dengan mudah dan efektif sehingga para petani bisa memperoleh hasil yang maksimal ketika musim panen. Alat ini bisa digunakan oleh para petani dengan pemantauan dirumah karena alat ini akan berjalan secara otomatis diarea persawahan para petani.
\end{abstract}

Kata kunci: Teknologi, Pertanian, Otomatis, Burung, Padi

\begin{abstract}
Technology in the growing field of agriculture with the help of increasingly sophisticated technology is very helpful to the farmers in improving agricultural products that they manage so as not to cause harm every penny. Autes Tech which is a tool that helps the community especially the farmers ahead of the harvest season when bird pests start meyerang when the harvest season with electronic systems this tool using the help of batteries or accumulator in the use of power and use the system of peregerakan with the help of timer every 5 minutes movement once. This tool can be used by farmers easily and effectively so that farmers can obtain maximum results during the harvest season. This tool can be used by farmers with home monitoring because this tool will run automatically in the rice fields of the farmers.
\end{abstract}

Keywords: technology, agriculture, automatic, bird, rice.

Jurnal Telematika Vol. 11 No. 1 Februari 2018 


\section{PENDAHULUAN}

Petani sering kali menghadapi kendala hama pada proses produksi. Hama burung menjadi musuh mereka ketika bulir padi sudah mulai kuncup. Hal yang biasa petani lakukan adalah membuat orang-orangan sawah tradisional yang dihubungkan dengan tali kendali yang memiliki panjang kurang lebih $10 \mathrm{~m}$ atau menggantung barang bekas pada tali kendali yang dibentangkan diatas sawah petani. Alat tradisional itu masih digerakkan menggunakan tenaga manusia. Oleh karena itu, petani harus menggerakan tali kendali dengan cara ditarik untuk mengusir burung yang datang ataupun hinggap sewaktu-waktu.

Perkembangan teknologi sudah semakin maju dan merambah ke segala sisi kehidupan. Teknologi membuat segala sesuatu dapat dilakukan dengan mudah. Manusia terus berinovasi untuk menciptakan sesuatu yang dapat mempermudah aktivitas. Hal tersebut merupakan dorongan agar teknologi terus berkembang. Sudah banyak teknologi yang menghasilkan alat untuk mempermudah aktivitas dan bahkan menggantikan peran manusia.

Pemanfaatan teknologi di bidang pertanian terus berkembang dari waktu ke waktu. Adanya teknologi modern yang diterapkan dalam bidang pertanian diharapkan dapat meningkatkan hasil produksi pertanian. Sebagian masyarakat di Indonesia menjadikan pertanian sebagai pekerjaan pokok. Dari hasil pertanian ini petani memperoleh penghasilan untuk mecukupi kebutuhan hidup mereka dan bahkan memperoleh kehidupan yang layak.

Timer NE555 salah satu bentuk teknologi sederhana yang dapat digunakan sebagai kontrol otomatis. Pemanfaatan timer dapat mempermudah kegiatan yang akan dilakukan serta menghemat waktu. Adapun penelitian sebelumnya yang dilakukan oleh Tri Watiningsih, Kholistianingsih, Dodi Wahjudi (2015) dengan judul Pengendali Waktu Penyiraman Pada Tanaman Hidroponik Menggunakan IC 555. Memanfaatkan IC 555 untuk mengatasi masalah lahan yang sempit dan pemberian air, yang pada prinsip kerja dari air bak dipompa ke pot tanaman secara otomatis. Arif Budi Laksono dan A.Rifki Zulfahmi Zahidi (2017) melakukan penelitian dengan judul Rancang Bangun Alat Pengusir Burung Pemakan Padi 
Berbasis Mikrokontroller Atmega328 dengan Sel Surya. Penelitian tersebut menghasilkan desain alat pengusir burung pemakan padi berbasis mikrokontroller Atmega 328 dengan sel surya. Amir D, dkk (2016) melakukan penelitian dengan judul IBM Teknologi Terapan Bagi Petani Sebagai Usaha Mencegah Serangan Hama Burung Pipit di Desa Blang Awe Kecamatan Syamtalira Bayu Kabupaten Aceh Utara. Hasil penelitian tersebut berupa alat pengusir hama burung menggunakan teknologi IbM, peneliti membuat alat pengusir burung dengan memanfaatkan gelombang ultrasonik dan sensor infra merah. Dari penelitian sebelumnya peneliti tertarik untuk melakukan penelitian alat pengusir burung pipit secara otomatis dengan memanfaatkan NE555 sebagai timer otomatis dan gerak motor wiper.

\section{METODE PENELITIAN}

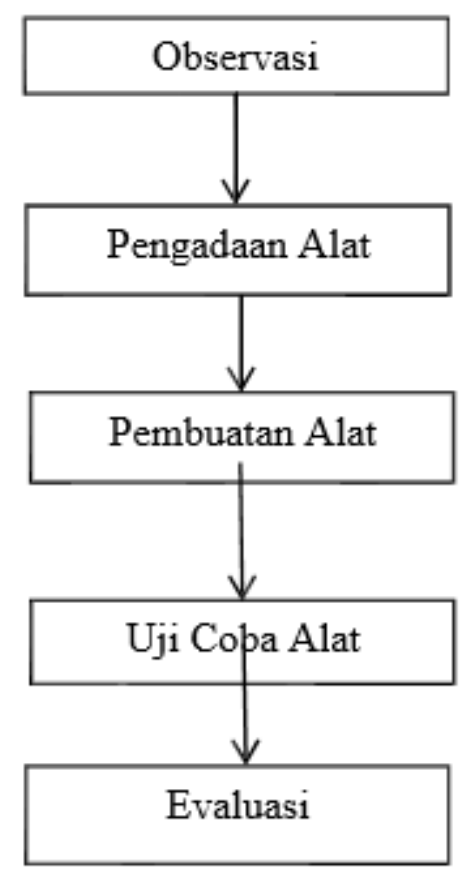

Gambar 1. Tahap pelakasanaan

Keterangan :

1. Observasi

Pada tahapan observasi bertujuan untuk melakukan observasi di desa yang 
akan digunakan untuk melakukan penelitian terhadap alat AUTES TECH, pada penelitian ini desa yang akan dijadikan sebagai tempat observasi yaitu Desa Pasinggangan, Kecamatan Banyumas, Kabupaten Banyumas dengan jumlah luas lahan persawahan yang cukup luas, sehingga dapat mengoptimalkan penggunaan alat yang akan digunakan, pada tahapan observasi ini juga bertujuan untuk melakukan penelitian terhadap alatalat yang sejenis untuk melihat kelebihan dan kekurangan dari alat yang sudah ada sebelumnya. Pada tahapan observasi ini akan mengetahui digunakan untuk memperoleh sebuah informasi yang akan digunakan oleh peneliti untuk mengetahui kebutuhan masyarakat untuk mengusir hama burung yang menyerang lahan pertanian masyarakat.

2. Pengadaan Alat dan Bahan

Tahapan selanjutnya yaitu tahapan yang digunakan untuk melakukan pengadaan alat dan bahan yang akan digunakan oleh peneliti untuk menciptakan sebuah alat pengusir burung AUTES TECH. Pada tahapan lanjutan setelah tahap observasi terlaksana, selanjutnya peneliti akan melakukan pengadaan alat dan bahan. Komponen bahan-bahan yang akan digunakan untuk membuat alat AUTES TECH seperti dibawah ini: a. Komponen bahan yang dibutuhkan :

- Resistor

- Serbuk Ferichloride

- PCB polos

- NE 555

- Motor Wipper

- Kertas Foto

b. Komponen Alat yang dibutuhkan

- Solder

3. Proses Pembuatan Alat

Setelah tahapan observasi dan pengadaan alat telah selesei dilaksanakan, pada tahapan selanjutnya yaitu tahapan untuk melakukan proses pembuatan 
alat AUTES TECH ini membutuhkan beberapa komponen elektronik yang digunakan sebagai alat pengendali.Pada proses pembuatan alat pembuatan dilakukan untuk membuat alat sehingga alat AUTES TECH bisa digunakan untuk mengusir hamar burung sawah yang menyerang para petani disawah.

4. Uji Coba Alat

Setelah tahapan produksi pembuatan alat Electric Scarecrow berhasil dibuat, selanjutnya adalah tahapan uji coba. Pada tahapan uji coba ini dilakukan di area persawahan untuk mengetahui fungsi alat terhadap hama burung yang menyerang padi . Pada tahapan uji coba alat ini akan dilakukan pengujian alat untuk menguji alat ini yaitu AUTES TECH di desa pasinggangan kabupaten Banyumas. Pengujian alat ini bertujuan untuk mengetahui kinerja dari AUTES TECH ini untuk mengusir hama burung yang menyerang persawahan para petani didesa pasinggangan sehingga menyebabkan kerugian yang dialami oleh masyarakat.

5. Evaluasi

Langkah terakhir setelah tahapan diatas selesei dilaksanakan, maka tahapan yang terakahir adalah melakukan evaluasi terhadap alat Electric Scarecrow yang akan diciptakan. Pada tahapan evaluasi disini akan melihat sejauh mana keberhasilan alat ini dibuat. Keberhasilan alat ini akan dinilai dengan melihat seberapa besar manfaat yang diberikan kepada masyarakat umum dengan melihat tingkat fungsi dari alat ini sendiri. Evaluasi akan digunakan untuk mengetahui manfaat dari AUTES TECH yang akan diketahui dari hasil proses pengujian alat ini untuk mengusir hama burung diarea persawahan masyarakat khususnya didesa pasinggangan. 


\section{HASIL DAN PEMBAHASAN}

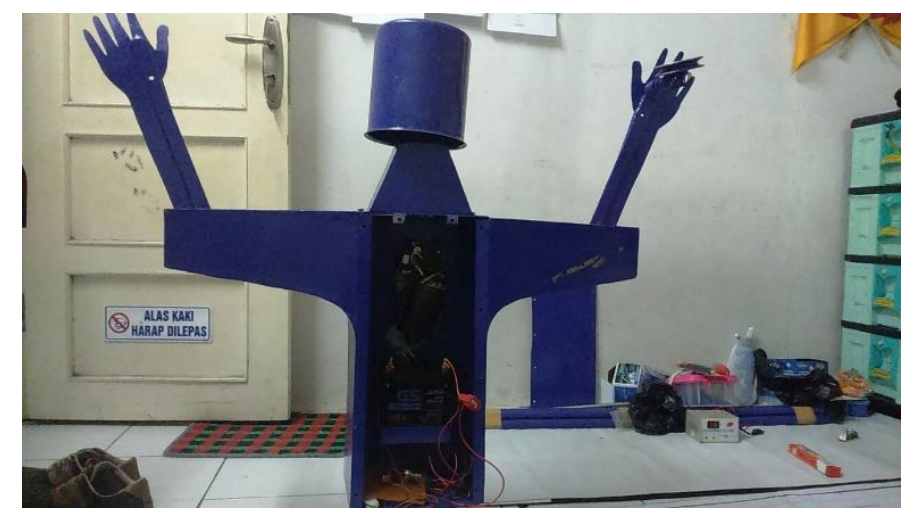

Gambar 2. Alat AUTES TECH

Alat Automatic Electric Scarecrow Technology ini merupakan pengembangan ilmu teknologi dibidang pertanian yang dapat digunakan oleh para petani untuk mengurangi hama burung ketika musim panen datang. Alat ini beroperasi menggunkan sumber tegangan yang bersumber dari accumulator ataau aki. Untuk mengatur jeda gerak setiap 5 menit sekali peneliti menggunakan rangkain timer NE 555 sehingga alat akan bergerak atau hidup selama lima menit dan mati selama lima menit.

Alat Autes Tech terbagi menjadi beberapa bagian yaitu, kepala, tangan, badan, dan kaki alat. Kepala alat, ketika alat hidup atau menyala maka tidak hanya tangan alat saja yang bergerak, tetapi bagian kepala juga akan bergerak dan berbunyi. Tangan alat, pada bagian tangan akan dihubungkan dengan tali pengait yang saling berhubungan sehingga akan menggerakkan kaleng bekas yang digantungkan pada tali. Badan alat, bagian ini terdiri dari ruang yang digunakan untuk menyimpan accumulator, motor wiper, dan rangkaian timer. Bagian kaki alat berfungsi sebagai penyangga badan alat.

Agar alat ini kokoh peneliti mendesain alat tersebut dari sebuah besi dan dilapisi dengan cat sehingga ketika alat ini terkena air hujan tidak mudah berkarat, dan alat ini juga digunakan dengan system tanam pada tanah. Alat ini akan melakukan pergerakan dan mengahsilkan sebuah bunyi dari gerakan alat ini.

Autes tech ini dibuat melalui tahapan perancangan alat, pembuatan alat dan 
yang terakhir pengujian alat. Pengujian alat dilakukan di desa pasinggangan kabupaten banyumas, didesa pasinggan merupakan sebuah wilayah desa dengan memiliki lahan persawahan cukup luas. Alat ini diujikan diwilayah peraswahan dengan lengan yang digunakan menggunakan sebuah tali untuk menarik pergerakan alat ini. Alat ini dipasang diarea persawangan dengan desain mirip dengan orang-orang sawah yang selama ini digunakan oleh masyarakat sekitar desa pasinganggan. Alat ini terdiri dari kepala, badan, dan bagian kaki, sehingga alat ini bisa bertahan lama atau bisa dilakukan pemsangan permanen diarea persawahan dengan seperti manusia dengan bagian bawah terdiri dari kaki, yang bisa beridiri sehingga bisa dilakukan pemasangan secara permanen agar kokoh ketika angin atau musim hujan turun. Alat ini pada bagian lengan akan menarik tali sehingga akan menghasilkan sebuah bunyi dari loncegan besi pada bagian kepala alat ini. Bunyi loncengan tersebut menggunakan waktu yang telah dibuat dari sebuah rangkain timer dengan bunyi yang dihasilkan yaitu setiap 5 menit sekali, bunyi itu bertujuan karena burung akan takut dengan suara, sehingga dengan adanya bunyi yang dihasilkan dari alat AUTES TECH ini burung-burung yang datang diarea persawahan pergi dari lingkungan area persawahan. Dengan adanya alat ini dari hasil penelitian yang dilakukan setelah diujikan di desa pasinggan, alat ini bisa membantu masyarakat khususnya para paguyuban tani di desa pasinggan yang selama ini mengeluh dengan adanya hama burung yang menyerang are pertanian masyarakat sehingga menyebabkan kerugian ketika musim panen datang. Dengan adanya alat ini digunakan untuk mengurangi tingkat hama khusunya menjelang musim panen dan membantu meningkatkan hasil panen para paguyuban tani sehingga hasil yang diperoleh akan maksimal dan tidak mengakibatkan laba atau kerugian untuk para petani.

\section{PENUTUP}

Dari hasil penelitian dan pembahasan dapat ditarik kesimpulan sebagai berikut:

1. Alat ini digunakan untuk mengusir hama burung oleh para petani pada musim panen untuk meningkatkan hasil panen para petani. Pada alat ini menggunakan 
2. Alat ini menggunakan sistem electronic dengan pengaturan pergerakan setiap 5 menit sekali.

3. Alat ini menggunakan bantuan aki sebagai sumber daya utama untuk mengerakan alat ini.

4. Alat ini akan menimbulkan suara ketika bergerak.

5. Alat ini masih masih menggunakan rangkain pergerakan dengan sistem timer 5 menit sekali dan belum bisa dilakukan pemantauan dari jarak yang jauh, dengan adanya alat ini diharapkan bisa dikembangkan dengan menggunakan bantuan teknologi sehingga pemantauan untuk pergerakan alat ini bisa dilakukan pada jarak yang jauh.

6. Alat ini masih menggunakan desain yang belum aman, karena untuk keamanan alat ini belum bisa terjamain, sehingga diharapkan alat ini bisa dikembangkan dengan menggunakan bantuan teknologi bisa membantu mengamankan alat ini dari pihak-pihak yang akan merugikan para petani.

\section{DAFTAR PUSTAKA}

Adha Prasetya O, Muid Abdul, Brianorman Yulrio, 2015. Prototipe Sistem Buka Tutup atap Jemuran Pakaian Menggunakan Mikrokontroler ATMEGA8. Url: http://www.e-jurnal.com.

Amir D, Indrawati, Akhyar. 2016.IBM Trknologi Terapan bai Petani Sebagai Usaha Mencegah Serangan Hama Burung Pipit di Desa Blang Awe Kecamatan Syamtalira Bayu Kabupaten Aceh Utara. Fakultas Teknik, Elektro Politeknik Negeri Lhokseumawe.

Arief Budi Laksono, A.Rifqi Zulfahmi Zahidi. 2017. Rancang Bangun Alat Pengusir Burung Pemakan Padi Berbasis Mikrokontroller Atmega328 Dengan Sel Surya. Fakultas Teknik, Elektro Universitas Islam Lamongan.

Kamus Besar Bahasa Indonesia (KBBI), Url : http://kbbi.web.id/tani. Diakses : 9 November 2016.

Karim Husnull, Asrizal, Yohandri. 2016, Pembuatan Sistem untuk Meratakan Pada Otomatis menggunakan Remote Control dan Detector Object. Universitas Negeri Padang. 
Watlningsih Tri, Kholistianingsih, Wahyudi Dodi. 2013. Pengendali Waktu Penyiraman pada Tanaman Hidroponik Menggunakan IC 555. Fakultas Teknik, Universitas Wijayakusuma Purwokerto. 